\title{
KINERJA APARATUR SEKRETARIAT DEWAN PERWAKILAN RAKYAT DAERAH (DPRD) KABUPATEN SINTANG DALAM PENYELENGGARAAN ADMINISTRASI KESEKRETARIATAN
}

\author{
Robert Hoffman \\ Fakultas Hukum Universitas Kapuas Sintang \\ Jalan Oevang Oeray 92 Sintang \\ Email : tobingunka@gmail.com dan tobing_unka@yahoo.com
}

\begin{abstract}
Organizational performance is an achievement or work result in activities or activities or programs that have been previously planned in order to achieve goals and targets set by an organization and implemented within a certain period.

The success of an organization to achieve objectives and targets set within a certain period of time must be realized with the availability of skilled human resources (HR), facilities and infrastructure owned in the implementation of work, and the availability of budget financing.
\end{abstract}

Keywords : Performance, Administration, Secretariat.
Abstrak
Kinerja organisasi merupakan suatu capaian atau hasil kerja dalam kegiatan atau aktivitas atau program yang telah direncanakan sebelumnya guna mencapai tujuan serta sasaran yang telah ditetapkan oleh suatu organisasi dan dilaksanakan dalam jangka waktu tertentu.

Keberhasilan suatu organisasi untuk mencapai tujuan dan sasaran yang ditetapkan dalam jangka waktu tertentu harus diwujudkan dengan ketersediaan sumber daya manusia (SDM) yang terampil, sarana dan prasarana yang dimiliki dalam pelaksanaan pekerjaan, serta ketersediaan anggaran pembiayaan.

Kata Kunci : Kinerja, Administrasi, Sekretariat.

\section{Latar Belakang}

Peraturan Daerah Kabupaten Sintang Nomor 2 Tahun 2008 tentang Struktur Organisasi Perangkat Daerah (SOPD) menempatkan Sekretariat Dewan Perwakilan Rakyat Daerah (DPRD) Kabupaten Sintang sebagai unsur pelayanan terhadap DPRD Kabupaten Sintang. Unsur pelayanan tersebut salah satunya meliputi tugas penyelenggaraan administrasi kesekretariatan. Selanjutnya, Sekretariat DPRD Kabupaten Sintang dalam melaksanakan tugas tersebut menyelenggarakan fungsi diantaranya penyelenggaraan administrasi kesekretariatan DPRD. Sekretariat DPRD Kabupaten Sintang 
dipimpin oleh sekretaris Dewan Perwakilan Rakyat Daerah (Sekwan) yang secara teknis operasional berada di bawah dan bertanggung jawab kepada pimpinan DPRD dan secara administratif bertanggung jawab kepada Bupati Sintang melalui sekretaris daerah. Oleh karena itulah peranan Sekretariat DPRD Kabupaten Sintang yang dipimpin oleh Sekwan sangat strategis peranannya.

Istilah kinerja merupakan terjemahan dari performance yang dapat diartikan sebagai prestasi, bisa pula berarti hasil kerja. Ada banyak pendapat ahli yang mengartikan tentang istilah kinerja. Menurut Keban, (2004 : 191) bahwa istilah kinerja sering diartikan oleh para cendekiawan sebagai “penampilan," "unjuk kerja," atau "prestasi." Menurut Bastian (dalam Tangkilisan, 2005

: 175) bahwa kinerja organisasi merupakan gambaran mengenai tingkat pencapaian pelaksanaan tugas dalam suatu organisasi, dalam mewujudkan sasaran, tujuan, misi, dan visi organisasi tersebut. Begitu juga menurut Encyclopedia of Public Administration and Public Policy Tahun 2003 (dalam Keban, 2004 : 193), bahwa kinerja dapat memberikan gambaran tentang seberapa jauh organisasi mencapai hasil ketika dibandingkan dengan pencapaian tujuan dan target yang telah ditetapkan.

Kinerja organisasi merupakan suatu capaian atau hasil kerja dalam kegiatan atau aktivitas atau program yang telah direncanakan sebelumnya guna mencapai tujuan serta sasaran yang telah ditetapkan oleh suatu organisasi dan dilaksanakan dalam jangka waktu tertentu yang dipengaruhi oleh beberapa faktor, diantaranya adalah faktor sumber daya manusia (SDM), sarana dan prasarana, serta anggaran pembiayaan. Hal ini mengartikan bahwa keberhasilan suatu organisasi untuk mencapai tujuan dan sasaran yang ditetapkan dalam jangka waktu tertentu harus diwujudkan dengan ketersediaan sumber daya manusia (SDM) yang terampil, sarana dan prasarana yang dimiliki dalam pelaksanaan pekerjaan, serta ketersediaan anggaran pembiayaan. Jadi, dengan kata lain berhasil-tidaknya kinerja suatu organisasi dipengaruhi oleh ketersediaan sumber daya manusia (SDM) yang terampil, sarana dan prasarana yang dimiliki dalam pelaksanaan tugas pokok dan fungsi, serta ketersediaan anggaran pembiayaan.

Berdasarkan kondisi yang terlihat dalam penelitian ini bahwa kinerja Sekretariat DPRD Kabupaten Sintang (termasuk didalamnya penyelenggaraan administrasi kesekretariatan) dikatakan sangat berhasil padahal diketahui terdapat hambatanhambatan yang dihadapi? Selanjutnya, meskipun ada hambatan-hambatan yang 
dihadapi namun keberhasilan apa saja yang telah dilaksanakan Sekretariat DPRD Kabupaten Sintang dalam penyelenggaraan administrasi kesekretariatan?

Berdasarkan permasalahan tesrebut maka peneliti tertarik untuk mengadakan penelitian ini yang diberi judul : Kinerja Aparatur Sekretariat Dewan Perwakilan Rakyat Daerah (DPRD) Kabupaten Sintang Dalam Penyelenggaraan Administrasi Kesekretariatan.

\section{Pembahasan}

\section{A. Deskripsi Wilayah Penelitian}

Kabupaten Sintang terletak di bagian timur Provinsi Kalimantan Barat atau di antara $1^{\circ} 05^{\prime}$ Lintang Utara serta $0^{\circ} 46^{\prime}$ Lintang Selatan dan $110^{\circ} 50^{\prime}$ Bujur Timur serta $113^{\circ} 20^{\prime}$ Bujur Timur. Batas wilayah administratif Kabupaten Sintang yaitu : Sebelah Utara : berbatasan dengan Kabupaten Kapuas Hulu dan Malaysia Timur (Serawak), Sebelah Selatan : berbatasan dengan Propinsi Kalimantan Tengah, Kabupaten Melawi, Kabupaten Sanggau dan Kabupaten Ketapang, Sebelah Timur : berbatasan dengan Propinsi Kalimantan Tengah, Kabupaten Sanggau dan Kabupaten Kapuas Hulu, dan Sebelah Barat : berbatasan dengan Kabupaten Ketapang, Kabupaten Sanggau, Kabupaten Melawi, Kabupaten Kapuas Hulu dan Kabupaten
Sekadau.

Kabupaten Sintang merupakan kabupaten yang memiliki luas wilayah ketiga terbesar di Propinsi Kalimantan Barat setelah Kabupaten Ketapang dan Kabupaten Kapuas Hulu. Berdasarkan data Kabupaten Sintang dinyatakan bahwa luas wilayah Kabupaten Sintang yaitu : $21.635 \mathrm{~km} 2$ dengan wilayah terluas terdapat di Kecamatan Ambalau yaitu : $6.386,40 \mathrm{~km} 2$ atau sebesar 29,52 persen, sedangkan Kecamatan Sintang merupakan wilayah kecamatan yang terkecil dengan luas wilayahnya yaitu $277,05 \mathrm{~km} 2$ atau hanya sebesar 1,28 persen. Dari luas tersebut, sebagian besar merupakan wilayah perbukitan dengan luas sekitar $13.573,75 \mathrm{~km} 2$ atau 62,74 persen.

Berdasarkan data Kabupaten Sintang, dinyatakan bahwa penduduk Kabupaten Sintang hingga mencapai 371.322 jiwa yang terdiri dari 191.824 laki-laki dan 179.498 perempuan. Untuk jelasnya, dapat dilihat dalam tabel dibawah ini.

Tabel 1. Komposisi Penduduk Kabupaten Sintang Berdasarkan Jenis Kelamin,

\begin{tabular}{|c|l|c|c|c|}
\hline No. & \multicolumn{1}{|c|}{ Kecamatan } & Laki-laki & Perempuan & Jumlah \\
\hline 1. & Serawai & 11.517 & 10.907 & 22.424 \\
\hline 2. & Ambalau & 6.736 & 6.343 & 13.079 \\
\hline 3. & Kayan Hulu & 11.254 & 11.072 & 22.326 \\
\hline 4. & Sepauk & 24.935 & 23.040 & 47.975 \\
\hline 5. & Tempunak & 14.459 & 13.136 & 27.595 \\
\hline 6. & Sungai Tebelian & 15.593 & 14.302 & 29.895 \\
\hline 7. & Sintang & 32.325 & 31.241 & 63.566 \\
\hline 8. & Dedai & 14.599 & 13.646 & 28.245 \\
\hline 9. & Kayan Hilir & 13.022 & 11.933 & 24.955 \\
\hline 10. & Kelam Permai & 8.050 & 7.568 & 15.618 \\
\hline 11. & Binjai Hulu & 6.098 & 5.648 & 11.746 \\
\hline
\end{tabular}




\begin{tabular}{|c|l|c|c|c|}
\hline 12. & Ketungau Hilir & 10.939 & 10.157 & 21.096 \\
\hline 13. & Ketungau Tengah & 14.669 & 13.635 & 28.304 \\
\hline 14. & Ketungau Hulu & 10.659 & 9.707 & 20.366 \\
\hline \multicolumn{2}{|c|}{ Total : } & 194.855 & 182.335 & 377.190 \\
\hline
\end{tabular}

Sumber Data : Badan Statistik Kabupaten Sintang.

Berdasarkan tabel tersebut, jumlah penduduk terbanyak di Kabupaten Sintang terdapat di wilayah Kecamatan Sintang yang mencapai 63.566 orang, terdiri atas 32.325 laki-laki dan 31.241 perempuan. Selain itu, bila dibandingkan dengan tahun-tahun sebelumnya, penduduk di Kabupaten Sintang selalu mengalami peningkatan. selanjutnya untuk mengetahui komposisi pegawai di Kabupaten Sintang dapat dilihat pada tabel berikut ini :

Tabel 3. Komposisi Pegawai Negeri Sipil Daerah Kabupaten Sintang berdasarkan Jenis Kelamin, .

\begin{tabular}{|c|c|c|}
\hline No & Jenis Kelamin & Jumlah \\
\hline 1. & Laki-Laki & 3643 \\
\hline 2. & Perempuan & 2485 \\
\hline \multicolumn{2}{|c|}{ Total } & 6128 \\
\hline
\end{tabular}

Sumber Data : Badan Statistik Kabupaten Sintang.

Dari tabel tersebut terlihat bahwa pegawai negeri sipil daerah di Kabupaten Sintang didominasi oleh laki-laki dengan jumlah 3643 orang. Selain itu, bila dilihat dari golongannya, maka keberadaan pegawai negeri sipil daerah Kabupaten Sintang memiliki golongan yang bervariasi mulai dari golongan I, II, III dan IV, sebagaimana dipaparkan dalam tabel di bawah ini.
Tabel 4. Komposisi Pegawai Negeri Sipil Daerah Kabupaten Sintang berdasarkan Golongan.

\begin{tabular}{|c|c|c|c|c|}
\hline No & Golongan & Laki-Laki & Perempuan & Jumlah \\
\hline 1. & I & 62 & 4 & 66 \\
\hline 2. & II & 925 & 670 & 1595 \\
\hline 3. & III & 1542 & 1151 & 2693 \\
\hline 4. & IV & 1114 & 660 & 1774 \\
\hline \multicolumn{2}{|c|}{ Total } & 3643 & 2485 & 6128 \\
\hline
\end{tabular}

Sumber Data : Badan Statistik Kabupaten Sintang.

Berdasarkan tabel tersebut pegawai negeri sipil (PNS) daerah Kabupaten Sintang kebanyakan berada pada golongan III yang mencapai 2693 orang, terdiri dari 1542 PNS laki-laki dan 1151 PNS perempuan. Sedangkan bila dilihat dari eselon, maka pegawai negeri sipil daerah Kabupaten Sintang yang memiliki eselon berjumlah 642 orang, terdiri dari 509 laki-laki dan 133 perempuan. Eselon yang ada juga bervariasi mulai dari eselon II a, II b, III a, III b, IV a, dan IVb, sebagaimana dipaparkan dalam tabel di bawah ini.

Tabel 5. Komposisi Pegawai Negeri Sipil Daerah Kabupaten Sintang berdasarkan Eselon.

\begin{tabular}{|c|c|c|c|c|}
\hline No & Eselon & Laki-Laki & Perempuan & Jumlah \\
\hline 1. & II.a & 1 & 0 & 1 \\
\hline 2. & II.b & 22 & 2 & 24 \\
\hline 3. & III.a & 51 & 6 & 57 \\
\hline 4. & III.b & 73 & 16 & 89 \\
\hline 5. & IV.a & 294 & 92 & 386 \\
\hline 6. & IV.b & 68 & 17 & 85 \\
\hline \multicolumn{2}{|c|}{ Total } & 509 & 133 & 642 \\
\hline
\end{tabular}

Sumber Data : Badan Statistik Kabupaten Sintang. 
Berdasarkan data Kabupaten Sintang dalam Angka Tahun 2013 bahwa dalam penyebarannya, keberadaan pegawai negeri sipil daerah Kabupaten Sintang ditempatkan pada instansi-instansi atau lembaga di seluruh wilayah Kabupaten Sintang, mulai dari kantor-kantor satuan kerja perangkat daerah (SKPD), kantor-kantor kecamatan, sekolahsekolah negeri dan swasta, Rumah Sakit Umum Daerah dan lain sebagainya.

Sekretariat Dewan Perwakilan Rakyat Daerah Kabupaten merupakan salah satu perangkat daerah di wilayah pemerintahan kabupaten yang ditetapkan dalam Peraturan Daerah Kabupaten Sintang Nomor 2 Tahun 2008 tentang Struktur Organisasi PerangkatDaerah (SOPD). Peraturan Bupati Sintang Nomor

42 Tahun 2013 tentang Perubahan Atas Peraturan Bupati Sintang Nomor 29 Tahun 2008 tentang Susunan Organisasi dan Tata Kerja (SOTK) Sekretariat DPRD Kabupaten Sintang. Bagan susunan organisasi Sekretariat DPRD Kabupaten Sintang sebagaimana tercantum dalam lampiran Peraturan Bupati Sintang Nomor 42 Tahun 2013 tentang Perubahan Atas Peraturan Bupati Sintang Nomor 29 Tahun 2008 tentang Susunan Organisasi dan Tata Kerja (SOTK) Sekretariat DPRD Kabupaten Sintang dapat dilihat dibawah ini :

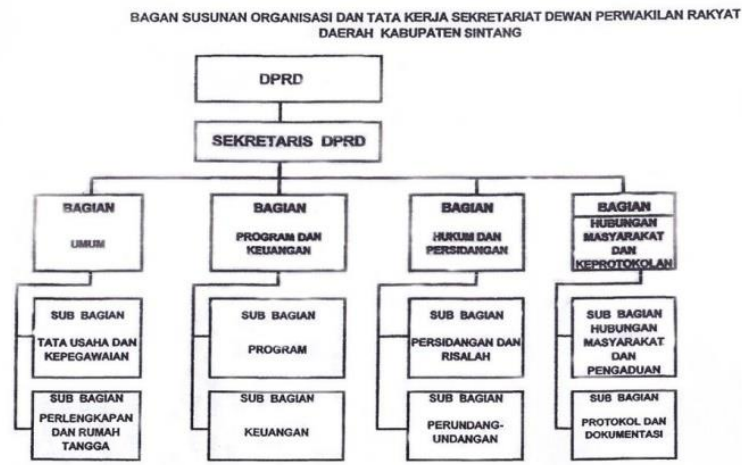

Sumber Data : Badan Statistik Kabupaten Sintang.

Komposisi pegawai negeri sipil daerah Kabupaten Sintang yang ditempatkan pada Sekretariat Dewan Perwakilan Rakyat Daerah Kabupaten Sintang bila dilihat dari tingkat golongan, didominasi oleh pegawai golongan II yang mencapai 20 orang, sebagaimana dalam tabel berikut ini.

Tabel 6. Komposisi Pegawai Negeri Sipil Daerah di Sekretariat Dewan Perwakilan Rakyat Daerah Kabupaten Sintang Berdasarkan Golongan.

\begin{tabular}{|c|c|c|}
\hline No & Golongan & Jumlah \\
\hline 1. & IV & 5 \\
\hline 2. & III & 17 \\
\hline 3. & II & 20 \\
\hline 4. & I & 1 \\
\hline 5 & Jumlah & 43 \\
\hline
\end{tabular}

Sumber Data : Sekretariat Dewan Perwakilan Rakyat Daerah Kabupaten Sintang.

Selanjutnya, komposisi pegawai negeri sipil di Sekretariat Dewan Perwakilan Rakyat Daerah Kabupaten Sintang bila dilihat dari tingkat eselon, berjumlah 22 orang, sebagaimana dalam tabel berikut ini.

Tabel 7. Komposisi Pegawai Negeri Sipil Daerah di Sekretariat Dewan Perwakilan Rakyat Daerah Kabupaten Sintang Berdasarkan Tingkat Eselon. 


\begin{tabular}{|c|c|l|c|}
\hline No & Eselon & \multicolumn{1}{|c|}{ Pangkat/Gol } & Jumlah \\
\hline 1. & II.b & Pembina Tk. I, IV/b & 3 \\
\hline 2. & III.a & Pembina, IV/a & 2 \\
\hline 3. & III.b & Penata Tk. I, III/d & 2 \\
\hline 4. & IV.a & Penata, III/c & 4 \\
\hline 5. & IV.b & Penata Muda Tk. I, III/b & 8 \\
\hline 6. & V & Penata Muda, III/a & 3 \\
\hline 7. & \multicolumn{3}{|c|}{ Jumlah : } \\
\hline
\end{tabular}

Sumber Data : Sekretariat DPRD Kabupaten Sintang.

Selanjutnya, komposisi pegawai negeri sipil di Sekretariat Dewan Perwakilan Rakyat Daerah Kabupaten Sintang bila dilihat dari tingkat pendidikan formal, didominasi oleh pegawai dengan tingkat pendidikan SD/SMP/ SMA yang berjumlah 25 orang, sebagaimana dalam tabel berikut ini.

Tabel 8. Komposisi Pegawai Negeri Sipil Daerah di Sekretariat Dewan Perwakilan Rakyat Daerah Kabupaten Sintang Berdasarkan Tingkat Pendidikan.

\begin{tabular}{|c|c|c|}
\hline No & Tingkat Pendidikan & Jumlah \\
\hline 1. & S2 & 7 \\
\hline 2. & S1 & 9 \\
\hline 3. & D3 & 2 \\
\hline 4. & SMP/SMA & 25 \\
\hline 5. & Jumlah & 43 \\
\hline
\end{tabular}

Sumber Data : Sekretariat DPRD Kabupaten Sintang.

\section{B. Kinerja Sekretariat DPRD Kabupaten Sintang dalam Penyelenggaraan Administrasi Kesekretariatan}

Sekretariat DPRD Kabupaten Sintang dalam menyelenggarakan administrasi kesekretariatan pada berpedoman pada Rencana Pembangunan Jangka Panjang Menengah Daerah (RPJMD) Sekretariat Daerah Kabupaten Sintang yang selanjutnya dituangkan dalam Rencara

Strategis (Renstra) Sekretariat DPRD Kabupaten Sintang. Hal ini sebagaimana dikatakan oleh Sekretaris DPRD Kabupaten Sintang kepada peneliti dari hasil wawancara.

Sekretaris DPRD Kabupaten Sintang kepada peneliti menjelaskan bahwa kedua dokumen RPJMD dan Renstra Sekretariat DPRD Kabupaten Sintang tersebut berisikan visi, misi, tujuan, sasaran dan indikator sasaran.

Sementara itu yang menjadi tujuan strategis Sekretariat DPRD Kabupaten Sintang menurut Sekretaris DPRD Kabupaten Sintang dalam penjabaran visi dan misi tersebut adalah : 1). Terwujudnya pelayanan prima terhadap DPRD Kabupaten Sintang, 2). Meningkatkan Sumber Daya Manusia (SDM) untuk menunjang pelayanan kepada anggota DPRD, dan 3). Terciptanya hubungan kerja yang sinergi antara legislatif dengan eksekutif. Sedangkan yang menjadi sasaran strategis dalam mencapai tujuan tersebut adalah : 1). Meningkatnya kelancararan pelaksanan persidangan rapat dan penyelenggaraan kegiatan DPRD, dan 2). Terciptanya keselarasan dan kesesuaian produk hukum. Indikator sasaran untuk mencapai kedua sasaran strategis tersebut yakni : 1). Meningkatnya kelancararan pelaksanan 
persidangan rapat dan penyelenggaraan kegiatan DPRD, dengan indikator sasaran meliputi : a). Jumlah rapat komisi yang difasilitasi sekeratariat, b). Jumlah rapat kerja yang difasilitasi sekretariat, c). Jumlah rapat dengar pendapat yang difasilitasi sekretariat, d). Jumlah rapat paripurna yang difasilitasi sekretariat, e). Jumlah rapat pimpinan yang difasilitasi sekretariat, dan f). Jumlah kunjungan kerja dan konsultasi yang difasilitasi; 2). Terciptanya keselarasan dan kesesuaian produk hukum dengan indikator sasaran meliputi : a). Jumlah aspirasi masyarakat yang ditampung dan diajukan kepada anggota DPRD, b). Jumlah Rancangan Peraturan Daerah yang diagendakan untuk dibahas dan disetujui oleh DPRD, c). Jumlah Raperda yang disetujui menjadi Perda, dan d). Jumlah produk Perda yang merupakan penetapan hak inisiatif DPRD.

Menurut Sekretaris DPRD Kabupaten Sintang bahwa kedua dokumen RPJMD dan Renstra yang berisi visi, misi, tujuan, sasaran dan indikator sasaran tersebut merupakan pedoman Sekretariat DPRD Kabupaten Sintang khususnya dalam menyelenggarakan administrasi kesekretariatan.

Berdasarkan hasil wawancara peneliti dengan Kepala Bagian Umum di Sekretariat DPRD Kabupaten Sintang diketahui bahwa penyelenggaraan administrasi kesekretariatan pada Sekretariat DPRD Kabupaten Sintang yang disesuaikan dengan visi, misi, tujuan, sasaran dan indikator sasaran yang tercantum dalam RPJMD dan Renstra Sekretariat DPRD Kabupaten Sintang dilaksanakan dengan mengadakan pengarsipan dokumen-dokumen penting di semua kegiatan. Menurut Kepala Bagian Umum di Sekretariat DPRD Kabupaten Sintang bahwa pengarsipan tersebut digunakan sebagai alat pertanggungjawaban dan sumber informasi manakala dokumen diperlukan.

Di samping itu, penyelenggaraan administrasi kesekretariatan pada Sekretariat DPRD Kabupaten Sintang juga dilaksanakan dengan mendistribusikan informasi ke seluruh pegawai sekretariat dan seluruh anggota DPRD, mengamankan kerahasiaan dokumen-dokumen arsip surat, mengelola dan memelihara seluruh dokumen tersebut yang berguna bagi kelancaran pelaksanaan tugas administrasi kesekretariatan. Menurut Kepala Bagian Umum di Sekretariat DPRD Kabupaten Sintang bahwa hal itu dilakukan dalam rangka ketatausahaan, alat komunikasi, dan pusat dokumen.

Berdasarkan hasil wawancara peneliti dengan Kepala Sub Bagian Umum dan Kepegawaian di Sekretariat DPRD Kabupaten Sintang diketahui bahwa pengarsipan yang dilakukan antara lain : surat-surat keputusan, risalah-risalah atau naskah sidang DPRD, 
66 Perahu, Volume 5 Nomor 2, September 2017, Hlm 59-72

surat-surat perjalanan dinas, dan surat-surat lainnya. Semua dokumen itu disimpan dalam rangka mengamankan kerahasiaan dokumen serta sebagai upaya untuk memeliharanya keaslian dokumen.

Berdasarkan hasil wawancara peneliti dengan Staf di Bagian Umum Sekretariat DPRD Kabupaten Sintang diketahui bahwa penyusunan arsip dilakukan dengan penomoran, penjilidan dan pembukuan. Arsip-arsip tersebut disimpan dalam rak sesuai dengan substansinya. Kalau substansinya surat tersebut berkenaan dengan surat keputusan (SK) maka surat tersebut dikelompokkan dalam kelompok SK dengan mencantumkan nomor urut yang kemudian pada tahun anggaran berakhir maka SK-SK itu dijilid atau dibundel. Setelah dibundel maka surat-surat tersebut disimpan dalam rak lemari yang telah disediakan dan setelah itu catat dalam pembukuan. Hal ini dilakukan untuk memudahkan pencarian bila saja surat tersebut diperlukan.

Berdasarkan hasil wawancara peneliti dengan Sekretaris DPRD Kabupaten Sintang diketahui bahwa penyelenggaraan administrasi kesekretariatan telah ditetapkan dalam penetapkan kinerja sebagai satu kesatuan yang tidak terpisah dari penetapan kinerja program kegiatan Sekretariat DPRD Kabupaten Sintang, sebab seluruh program kegiatan Sekretariat DPRD tersebut tentu memerlukan kegiatan pengadministrasian. Menurutnya penetapan kinerja tersebut dalam rangka mewujudkanmanajemen pemerintahan yang efektif, transparan dan akuntabel.

Sekretaris DPRD Kabupaten Sintang kepada peneliti mengatakan bahwa untuk mengukur keberhasilan Sekretariat DPRD Kabupaten dalam menyelenggarakan administrasi kesekretariatan pada dapat diukur dari pencapaian indikator kinerja Sekretariat DPRD Kabupaten Sintang secara keseluruhan berdasarkan daftar penetapan kinerja. Pencapaian indikator kinerja tersebut dapat dijelaskan dalam tabel berikut ini : 
Tabel 9. Pencapaian Kinerja Sekretaris DPRD Kabupaten Sintang .

\begin{tabular}{|c|c|c|c|c|c|c|}
\hline No & Sasaran & $\begin{array}{c}\text { Indikator } \\
\text { Pencapaian } \\
\text { Sasaran }\end{array}$ & Satuan & Target & Realisasi & $\begin{array}{c}\text { Capaian } \\
\text { Kinerja } \\
(\%)\end{array}$ \\
\hline \multirow[t]{12}{*}{1.} & \multirow{12}{*}{\begin{tabular}{|l|}
\multicolumn{2}{|c|}{ Meningkatnya } \\
kelancaran pe- \\
laksanaan per- \\
sidangan rapat \\
dan penyeleng- \\
garaan kegiatan \\
DPRD
\end{tabular}} & $\begin{array}{|lr|}\text { Jumlah } & \text { Rapat } \\
\text { Komisi } & \text { yang } \\
\text { d i f a si l li t a si } \\
\text { sekretariat }\end{array}$ & & 15 kali & 15 kali & - \\
\hline & & $\begin{array}{|lr|}\text { Jumlah } & \text { rapat } \\
\text { kerja } & \text { yang } \\
\text { dif a si l i t a si } \\
\text { sekretariat } \\
\end{array}$ & & 35 kali & 35 kali & - \\
\hline & & \begin{tabular}{|l|}
$\mathrm{J}$ u $\mathrm{m} \mathrm{l}$ a $\mathrm{h}$ \\
rapat dengar \\
pendapat yang \\
d i f a si l lit a s \\
sekretariat
\end{tabular} & & 5 kali & 5 kali & - \\
\hline & & $\begin{array}{|ll|}\text { Jumlah } & \text { rapat } \\
\text { paripurna } & \text { yang } \\
\text { dif a si li } & \text { it a si } \\
\text { sekretariat } & \\
\end{array}$ & & 29 kali & 35 kali & - \\
\hline & & $\begin{array}{|lr|}\text { Jumlah } & \text { rapat } \\
\text { pimpinan } & \text { yang } \\
\text { dif a si li } & \text { it a si } \\
\text { sekretariat. }\end{array}$ & & - & 6 kali & - \\
\hline & & 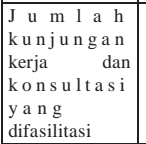 & & 6 kali & - & - \\
\hline & & \begin{tabular}{|l} 
Peningkatan kapa \\
\end{tabular} & asitas Le & mbaga Perwakila & in Rakyat Daeral & \\
\hline & & \begin{tabular}{|l|}
$\begin{array}{l}\text { a. Ke gi a t a n } \\
\text { Reses }\end{array}$ \\
\end{tabular} & Tahun & 1.153 .045 .000 & 1.091 .754 .000 & 94.68 \\
\hline & & 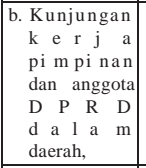 & Tahun & 655.900 .000 & 423.767 .000 & 64.61 \\
\hline & & \begin{tabular}{|r|} 
c. Peningkatan \\
ka pa sit a s \\
pi m pi nan \\
dan anggota, \\
\end{tabular} & Tahun & 2.595 .965 .000 & 1.191 .988 .000 & 76.73 \\
\hline & & \begin{tabular}{|l|} 
d. $\begin{array}{c}\text { Penyediaan } \\
\text { jasa jaminan } \\
\text { kesehatan, }\end{array}$ \\
\end{tabular} & Tahun & 287.980 .000 & 269.955 .000 & 93.74 \\
\hline & & \begin{tabular}{|l|} 
e. Koordinasi \\
d e n g a n \\
pemerintah \\
pusat dan \\
pemerintah \\
d a er a h \\
lainnya. \\
\end{tabular} & Tahun & 1.611 .620 .000 & 1.527 .182 .000 & 94.76 \\
\hline \multirow[t]{10}{*}{2.} & \multirow[t]{10}{*}{\begin{tabular}{|l|} 
Terciptanya \\
keselarasan \\
dan kesesuaian \\
produk hukum
\end{tabular}} & 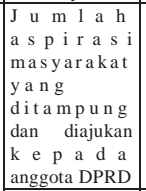 & & 30 kali & 30 kali & - \\
\hline & & \begin{tabular}{|l|}
$\mathrm{J}$ u $\mathrm{m} \mathrm{l}$ a $\mathrm{h}$ \\
$\mathrm{Ra}$ nc a ng a \\
$\mathrm{P}$ e r a t u r a \\
Daerah yang \\
diagendakan \\
untuk dibahas \\
dan disetujui \\
oleh DPRD \\
\end{tabular} & & 16 buah & 16 buah & - \\
\hline & & 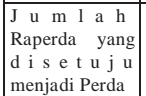 & & 10 buah & 10 buah & - \\
\hline & & $\begin{array}{|lr|}\text { Jumlah } & \text { produk } \\
\text { Perda } & \text { yang } \\
\text { m e rup a } & \text { ka } n \\
\text { p e n e t a p a n } \\
\text { hak } & \text { inisiatif } \\
\text { DPRD. } & \\
\end{array}$ & & - & & - \\
\hline & & \begin{tabular}{|l} 
Peningkatan kap \\
\end{tabular} & asitas Le & mbaga Perwakila & in Rakyat Daera & \\
\hline & & \begin{tabular}{|c|} 
1. Pembahasan \\
Raperda.
\end{tabular} & Tahun & 1.753.215.000 & 1.598.554.500 & \multirow{3}{*}{89.14} \\
\hline & & $\begin{array}{l}\text { 2. } \mathrm{R} \text { a } \mathrm{p} \mathrm{a} \mathrm{t}- \\
\text { rapat alat } \\
\text { kelengkapan } \\
\text { dewan. }\end{array}$ & Tahun & 147.641 .000 & 146.587 .500 & \\
\hline & & $\begin{array}{l}\text { 3. Rapat-rapat } \\
\text { paripurna. }\end{array}$ & Tahun & 239.765 .000 & 213.733 .000 & \\
\hline & & \begin{tabular}{|l|} 
P r o g r a m \\
pengembangan \\
komunikasi, \\
informasi dan \\
media massa. \\
\end{tabular} & - & - & - & - \\
\hline & & \begin{tabular}{|l|} 
Belanja iklan \\
pengumuman \\
media massa.
\end{tabular} & Tahun & 60.000 .000 & 59.285 .000 & 98.81 \\
\hline
\end{tabular}

Sumber Data : Hasil wawancara peneliti dengan Sekretaris DPRD Kabupaten Sintang.
Berdasarkan tabel tersebut Sekretariat DPRD Kabupaten Sintang, menurut Sekretaris DPRD Kabupaten Sintang kepada peneliti bahwa seluruh kegiatan dalam sasaran telah dilaksanakan sesuai target yang ditetapkan dalam daftar penetapan kinerja yakni : 1). Meningkatnya kelancararan pelaksanan persidangan rapat dan penyelenggaraan kegiatan DPRD, dengan indikator sasaran meliputi : a). Jumlah rapat komisi yang difasilitasi sekeratariat, b). Jumlah rapat kerja yang difasilitasi sekretariat, c). Jumlah rapat dengar pendapat yang difasilitasi sekretariat, d). Jumlah rapat paripurna yang difasilitasi sekretariat, e). Jumlah rapat pimpinan yang difasilitasi sekretariat, dan f). Jumlah kunjungan kerja dan konsultasi yang difasilitasi; 2). Terciptanya keselarasan dan kesesuaian produk hukum dengan indikator sasaran meliputi : a). Jumlah aspirasi masyarakat yang ditampung dan diajukan kepada anggota DPRD, b). Jumlah Rancangan Peraturan Daerah yang diagendakan untuk dibahas dan disetujui oleh DPRD, c). Jumlah Raperda yang disetujui menjadi Perda, dan d). Jumlah produk Perda yang merupakan penetapan hak inisiatif DPRD.

Berdasarkan hasil penelitian yang diperoleh tersebut, peneliti berpendapat bahwa kinerja Sekretariat DPRD Kabupaten Sintang dalam menyelenggarakan 
administrasi keseksekretariatan pada telah berhasil. Menurut peneliti keberhasilan tersebut menunjukan bahwa produktivitas, kualitas layanan, responsivitas, responsibilitas dan akuntabilitas Sekretariat DPRD Kabupaten Sintang telah diwujudkan dalam penyelenggaraan administrasi kesekretariatan. Pada produktivitas terlihat dari target dan realisasi penyelenggaraan administrasi kesekretariatan yang telah sesuai dalam . Sedangkan pada responsivitas terlihat adanya kemampuan pegawai Sekretariat DPRD Kabupaten Sintang dalam menyelenggarakan administrasi kesekretariatan. Sementara itu, pada akuntabilitas Sekretariat DPRD Kabupaten Sintang dalam penyelenggaraan administrasi kesekretariatan terlihat dalam bentuk pertanggungjawaban Sekretariat DPRD yang dituangkan dalam Laporan Akuntabilitas Kinerja Instansi Pemerintah (LAKIP) Sekretariat DPRD Kabupaten Sintang atas penyelenggaraan administrasi kesekretariatan.

C. Faktor-faktor yang mempengaruhi kinerja Sekretariat Dewan Perwakilan Rakyat Daerah (DPRD) Kabupaten Sintang dalam penyelenggaraan administrasi kesekretariatan

Kinerja Sekretariat DPRD Kabupaten Sintang dalam menyelenggarakanadministrasi kesekretariatan diketahui dipengaruhi oleh faktor pendukung dan faktor penghambat.
Berdasarkan hasil wawancara peneliti dengan Sekretaris DPRD Kabupaten Sintang bahwa faktor pendukung tersebut merupakan faktor yang membuat kinerja Sekretariat DPRD Kabupaten Sintang berhasil. Menurutnya, faktor-faktor pendukung tersebut antara lain :

1. Adanya wewenang Sekretariat DPRD untuk memberikan pelayanan dan tata laksana guna meningkatkan efisiensi dan efektivitas administrasi DPRD sesuai dengan peraturan perundangundangan.

2. Adanya kerjasama dan semangat atau etos kerja yang tinggi dari segenap personil Sekretariat DPRD Kabupaten Sintang untuk mengabdikan diri sebagai aparatur Negara sesuai dengan tugas pokok dan fungsi serta adanya dukungan dari pimpinan dalam setiap tugas pokok dan fungsi yang dilaksanakan.

Selain faktor pendukung tersebut, ada juga faktor yang menghambat kinerja Sekretariat DPRD Kabupaten Sintang dalam menyelenggarakan administrasi kesekretariatan, sebagaimana dijelaskan oleh Sekretaris DPRD Kabupaten Sintang kepada peneliti dari hasil wawancara peneliti bahwa faktor penghambat tersebut, antara lain :

1. Kurang tersedianya sarana dan prasarana kerja yang memadai dalam menunjang pelaksanaan tugas pokok dan fungsi.

2. Terbatasnya Sumber Daya Manusia (SDM) yang terampil sesuai dengan bidang tugasnya, tidak sebanding dengan volume kegiatan anggota DPRD yang sangat tinggi.

3. Terbatasnya pagu indikatif anggaran 
dalam APBD Kabupaten Sintang ditetapkan untuk membiayai kegiatan pengembangan peningkatan pelayanan kepada DPRD, sehingga pelayanan kepada anggota DPRD masih dirasakan belum optimal.

Sekretaris DPRD Kabupaten Sintang kepada peneliti mengatakan bahwa faktor pendukung dan faktor penghambat tersebut telah dituangkan dalam Laporan Akuntabilitas Kinerja Instansi Pemerintah (LAKIP) Sekretariat DPRD Kabupaten Sintang .

Sekretaris DPRD Kabupaten Sintang kepada peneliti mengatakan bahwa kurang tersedianya sarana dan prasarana kerja yang memadai dalam menunjang pelaksanaan tugas pokok dan fungsi, khususnya dalam penyelenggaraan administrasi kesekretariatan dikarenakan pada sarana dan prasarana yang tersedia di Sekretariat DPRD Kabupaten

Sintang adalah sebagai berikut :

a. Gedung Kantor Sekretariat DPRD Kabupaten Sintang terdiri dari 1 (satu) unit, yaitu gedung kantor yang merupakan Kantor Sekretariat DPRD, terletak di Jalan M. Saad Nomor 1 Sintang, disamping itu Sekretariat DPRD Kabupaten Sintang juga mengelola gedunggedung seperti : 1). Gedung Mess DPRD di Jalan M. Saad, Sintang dan 2). Rumah Jabatan Ketua DPRD Kabupaten Sintang di Jalan Imam Bonjol, Sintang.

b. Kendaraan yang tersedia yaitu hanya kendaraan air bermotor sebanyak 1 (satu) unit.

Sedangkan untuk kendaraan roda dua, kendaraan roda empat dan komputer pada tahun itu belum dimiliki Sekretariat DPRD Kabupaten Sintang. Namun demikian dalam penyelenggaraan administrasi kesekretariatan, Sekretariat DPRD Kabupaten Sintang menyediakan ruang kantor, lemari rak arsip, meja, kursi dan alat tulis kantor. Meskipun para pegawai belum disediakan kendaraan dinas maupun komputer, akan tetapi semuanya telah diusahakan oleh pegawai sendiri. Pada umumnya mereka menggunakan fasilitas pribadi dalam melaksanakan tugasnya.

Sekretaris DPRD Kabupaten Sintang kepada peneliti mengatakan bahwa terbatasnya sumber daya manusia (SDM) yang terampil sesuai dengan bidang tugasnya tidak sebanding dengan volume kegiatan anggota DPRD yang sangat tinggi, disebabkan oleh pengadaan tenaga administrasi pada belum pernah dilakukan. Demikian juga mengenai terbatasnya pagu indikatif anggaran dalam APBD Kabupaten Sintang yang ditetapkan untuk membiayai kegiatan pengembangan peningkatan penyelenggaraan adminitrasi kesekretariatan dikarenakan pada anggaran yang diusulkan terjadi pengurangan ketika pembahasan APBD Kabupaten Sintang yang dilakukan bersama antara anggota DPRD dan Bupati Sintang, sehingga pagu anggaran yang setujui hanya sebatas yang tertera pada daftar penetapan kinerja. Sehingga demikian, 
kegiatan Sekretariat DPRD Kabupaten Sintang harus disesuaikan dengan pagu anggaran yang ada.

Berdasarkan hasil wawancara peneliti dengan Kepala Bagian Umum di Sekretariat DPRD Kabupaten Sintang diketahui bahwa sumber daya manusia, sarana dan prasarana, dan anggaran menjadi faktor utama yang menghambat kinerja Sekretariat DPRD Kabupaten Sintang dalam menyelenggarakan administrasi kesekretariatan.

Begitu juga menurut Kepala Sub Bagian Umum dan Kepegawaian di Sekretariat DPRD Kabupaten Sintang dari hasil wawancara dengan peneliti mengatakan bahwa terbatasnya sumber daya manusia, sarana dan prasarana, dan anggaran pada membuat terbatasnya semua program penyelenggaraan administrasi kesekretariatan yang hanya mengikuti 2 (dua) kegiatan saja yaitu : pelaksanaan persidangan rapat dan mendokumentasikan produk hukum, padahal kegiatan di Sekretariat DPRD Kabupaten Sintang berdasarkan RPJMD dan Renstra sangat banyak sesuai dengan visi, misi, tujuan, sasaran dan indikator kinerja Sekretariat DPRD Kabupaten Sintang.

Berdasarkan hasil wawancara peneliti dengan Staf di Bagian Umum Sekretariat DPRD Kabupaten Sintang diketahui bahwa terbatasnya sumber daya manusia, sarana dan prasarana, dan anggaran dalam menyelenggarakan administrasi kesekretariatan pada terpaksa harus memanfaatkan apa yang ada, misalnya meskipun komputer belum disediakan namun komputer atau laptop milik pribadi sering dimanfaatkan dalam urusan administrasi kesekretariatan.

Berdasarkan hasil penelitian yang diperoleh tersebut, peneliti berpendapat bahwa kinerja Sekretariat DPRD Kabupaten Sintang dalam menyelenggarakan administrasi kesekretariatan pada yang meskipun dipengaruhi oleh faktor pendukung dan faktor penghambat namun pada umumnya kinerja tersebut telah berhasil. Hal ini dikarenakan pada umumnya pegawai di Sekretariat DPRD Kabupaten Sintang memanfaatkan ketersediaan yang ada termasuk milik pribadi.

\section{Simpulan}

Berdasarkan hasil penelitian yang diperoleh maka dapat disimpulkan bahwa :

1. Kinerja Sekretariat DPRD Kabupaten Sintang dalam penyelenggaraan administrasi kesekretariatan telah berhasil dilihat dari produktivitas, responsivitas, responbilitas dan akuntabilitas. Pada produktivitas terlihat dari target dan realisasi penyelenggaraan administrasi kesekretariatan. Sedangkan pada responsivitas terlihat adanya kemampuan pegawai Sekretariat DPRD Kabupaten Sintang dalam 
menyelenggarakan administrasi

kesekretariatan. Sementara itu, pada akuntabilitas Sekretariat DPRD Kabupaten Sintang dalam penyelenggaraan administrasi kesekretariatan terlihat dalam bentuk pertanggungjawaban Sekretariat DPRD yang dituangkan dalam Laporan Akuntabilitas Kinerja Instansi Pemerintah (LAKIP) Sekretariat DPRD Kabupaten Sintang atas penyelenggaraan administrasi kesekretariatan.

2. Faktor-faktor yang mempengaruhi Kinerja Sekretariat DPRD Kabupaten Sintang dalam penyelenggaraan administrasi kesekretariatan pda terdiri dari faktor pendukung dan penghambat. Faktor pendukung yaitu

: a). Adanya wewenang Sekretariat DPRD untuk memberikan pelayanan dan tata laksana guna meningkatkan efisiensi dan efektivitas administrasi DPRD sesuai dengan peraturan perundang-undangan, dan b). Adanya kerjasama dan semangat atau etos kerja yang tinggi dari segenap personil Sekretariat DPRD Kabupaten Sintang untuk mengabdikan diri sebagai aparatur Negara sesuai dengan tugas pokok dan fungsi serta adanya dukungan dari pimpinan dalam setiap tugas pokok dan fungsi yang dilaksanakan. Faktor penghambat yaitu : a). Kurang tersedianya sarana dan prasarana kerja yang memadai dalam menunjang pelaksanaan tugas pokok dan fungsi, b). Terbatasnya Sumber Daya Manusia (SDM) yang terampil sesuai dengan bidang tugasnya, tidak sebanding dengan volume kegiatan anggota DPRD yang sangat tinggi, dan c). Terbatasnya pagu indikatif anggaran dalam APBD Kabupaten Sintang ditetapkan untuk membiayai kegiatan pengembangan peningkatan pelayanan kepada DPRD, sehingga pelayanan kepada anggota DPRD masih dirasakan belum optimal. Kinerja Sekretariat DPRD Kabupaten Sintang dalam menyelenggarakan administrasi kesekretariatan pada yang meskipun dipengaruhi oleh faktor pendukung dan faktor penghambat namun pada umumnya kinerja tersebut telah berhasil. Hal ini dikarenakan pada umumnya pegawai di Sekretariat DPRD Kabupaten Sintang memanfaatkan ketersediaan yang ada termasuk milik pribadi.

\section{DAFTAR PUSTAKA}

\section{Buku-Buku}

Anthony, Robert N. dan Vijay Govindarajan. 1998. Management Control System. Ninth Edition. Mc Grow Hill : Illionis. Inc.

Ambarriani, Susty. A. 2000. Manajemen Biaya. Jakarta : Salemba Empat.

Dwiyanto, Agus. 2006. Mewujudkan Good Governance Melayani Publik. Yogyakarta : Gadjah Mada University.

Kamus Besar Bahasa Indonesia. 1996. Jakarta : Balai Pustaka.

Gie, T.L. 2005. Administrasi Perkantoran Modern. Yogyakarta : Liberty.

Handayaningrat, Soewarno. 1996. Pengantar Studi Ilmu Administrasi dan Manajemen. Jakarta : Gunung Agung.

Hasibuan, Malayu. 1996. Organisasi dan Motivasi dan Dasar-Dasar Peningkatan Produktivitas. Jakarta : Bumi Aksara.

Keban, Yeremias. T. 2004. Enam Dimensi 
Strategis Administrasi Publik,

Konsep, Teori, dan Isu. Yogyakarta

: Gava Media.

Prawirosentono, Suyadi. 1999. Kebijakan

Kinerja Karyawan. Yogyakarta : BPFE.

Mangkunegara, Anwar Prabu. 2006. Evaluasi Kinerja SDM. Bandung : Refika Aditama.

Notoatmodjo, S. 2003. Pengantar Pendidikan dan Ilmu Perilaku Kesehatan. Yogyakarta : Andi offset.

Ratminto dan Winarsih, Atik Septi. 2005. Manajemen Pelayanan. Yogyakarta : Penerbit Pustaka Pelajar.

Sedarmayanti. 1997. Tugas dan

Pengembangan Sektretaris. Bandung :

MandarMaju.

Supriyatno, Budi. 2009. Manajemen Pemerintahan. Tangerang : Media Brilian.

Supriyono R. A. 1994. Akuntansi Biaya Pengumpulan Biaya dan Penentuan Harga Pokok Buku I Edisi Ke-2. Yogyakarta : BPFE-UGM.

Tangkilisan, Hessel Nogi S. 2005. Manajemen Publik. Jakarta : Gramedia Pustaka.

Thoha, Miftah. 1993. Perilaku Organisasi Konsep Dasar dan Aplikasinya. Cetakan Ke Enam. Jakarta : Raja Grafindo Persada.

Tunggal, Amin Widjaya. 1996. Dasar-Dasar Budgeting. Jakarta : Rineka Cipta.

Webster's New World Dictionary of the American Language. 1956.

Winarno, B. 2005. Teori dan Proses Kebijakan Publik. Yogyakarta : Media Presindo.
Peraturan Perundang-undangan :

Undang-Undang Nomor 32 Tahun 2004 tentang Pemerintahan Daerah, sebagaimana telah dua kali diubah terakhir dengan Undang-Undang Nomor 12 Tahun 2008 tentang Pemerintahan Daerah.

Peraturan Daerah Kabupaten Sintang Nomor 2 Tahun 2008 tentang Struktur Organisasi Perangkat Daerah.

\section{Data Penunjang :}

Laporan Akuntabilitas Kinerja Instansi Pemerintah (LAKIP) Sekretariat DPRD Kabupaten Sintang. 